\title{
El perfil de les competències professionals del professorat de l'ESO
}

\author{
Zoia Bozu \\ Grup FODIP (Formació Docent i Innovació Pedagògica), Universitat de Barcelona \\ zoiabozu@hotmail.com
}

Avui més que mai la professió de la docència afronta diversos reptes. I un d'ells és la formació per competències. Són molts els estudis, les investigacions i les experiències que s'han produït o s'estan produint $i$ circulant en el nostre medi professional sobre aquesta temàtica. El propòsit d'aquest article es proporcionar una recopilació teòrica i reflexiva sobre la temàtica de les competències professionals del professorat de l'ESO.

Paraules clau: formació del professorat, competència docent, perfil competencial, ensenyament secundari

\section{APROXIMACIÓ AL CONCEPTE DE COMPETENNCIES}

\subsection{De què parlem quan parlem de competències?}

El concepte de competència s'obre camí arreu. Va néixer en el context de la formació professional i s'està expandint al conjunt del sistema educatiu. També s'utilitza en els processos de formació continua.

La gestió per competències s'ha convertit, en els últims anys, en un model integrador i orientador de les diferents polítiques de Recursos Humans. Malgrat que les principals experiències i les més nombroses es produeixen en empreses privades, progressivament el mon educatiu està apostant per aquest model, assumint els reptes i avantatges que comporta.

La literatura sobre el tema contempla diverses accepcions del terme "competència". Normalment identifiquen les competències amb característiques de la persona relacionades amb una actuació d'èxit en el seu lloc de treball.

En un intent de fer una síntesi, després d'analitzar un elevat nombre de definicions de la competència, elaborades per una gran diversitat d'autors $i$ d'instàncies nacionals i internacionals, tant educatives como professionals, podem extreure'n alguns elements comuns a tenir en compte:
- En el concepte de competència se integra el saber, el saber fer i el saber ser.

- Es constitueixen per coneixements, habilitats i actituds que produeixen resultats tangibles. I la seva mesura ens informa del grau de domini aconseguit.

- Té relació amb l'acció: es desenvolupa, s'actualitza en la acció.

- Està vinculada a un context, a una situació donada.

- Facilita la resolució eficaç de situacions laborals conegudes o inèdites.

- És educable.

\subsection{Tipus de competències}

La varietat de concepcions sobre el concepte de competència ens remet a un altre aspecte, no menys important: les classes o tipus de competència que existeixen.

A continuació, procedim a enumerar algunes tipologies de competències, com serien per exemple:

1) Des de una perspectiva cognitivista: competència interpretativa, competència argumentativa, competència propositiva.

2) Des de una perspectiva més actualitzada i de major profunditat, s'estableixen tres tipus de competències: cognitives - procedimentals actitudinals. 
3) Les competències en les tres realitats popperianes (Realitats Objectives, Realitats Intra-InterSubjectives, Realitats Culturals).

4) Les competències segon el tipus d'estructura mental: Competències Instrumentals i Competències Operacionals (Pacheco, 2005).

A l'àmbit de la didàctica i des d'una perspectiva curricular parlem de competències disciplinàries 0 especifiques i transversals o genèriques. En el camp de la formació del professorat identifiquem el concepte de competència professional, com a base per al model de formació.

\section{EL PERFIL COMPETENCIAL DEL PROFESSORAT DE L'ENSENYAMENT SECUNDARI}

Entenem que el perfil professional ha d'ésser una descripció detallada i acurada que mostri els trets més característics d'un grup professional. Quan parlem del perfil professional del professorat, ens referim al conjunt de capacitats i competències que identifiquen la formació d'una persona per a assumir en condiciones optimes les responsabilitats pròpies del desenvolupament de funcions i tasques de la seva professió.

Dient-ho d'una altra manera, definir el perfil professional del professorat significa definir les seves funciones, les atribucions, els àmbits d'actuació i competències professionals.

Als apartats següents ens proposem definir i delimitar les competències professionals del professorat de secundaria.

\subsection{Què entenem per competències professionals del docent?}

En la majoria de les definicions de competència professional es reconeix que aquesta expressió no es limita al conjunt de habilitats o destreses requerides per intervenir adequadament en un context determinat. És a dir, que no es limita a la simple execució de tasques, sinó que també involucra una combinació d'atributs respecte a saber, saber fer i saber ser (Projecte Tunning, 2003).

Per això, les competències professionals del professorat es poden definir com el conjunt de coneixements, habilitats, actituds i valors necessaris per realitzar una docència de qualitat.

Això és: el que han de saber i saber fer els professors i professores per abordar de forma satisfactòria els problemes que l'ensenyament els planteja.

\subsection{Referencial de competències professionals docents a l'ensenyament secundari}

Les competències del professorat de secundaria es deriven de les funcions professionals que li correspon realitzar en la actualitat. I funcions generals del professorat de secundaria són planificar i implementar el currículum escolar, tutoritzar els alumnes, donar-los suport en el context familiar i social, actualitzar-se i implicar-se en la professió docent.

La literatura sobre el tema ens ofereix una multitud de llistats de competències per al professorat de secundaria. A continuació n'enumerem i analitzem algunes.

Perrenaud (2004) proposa "Deu dominis de competències" considerats prioritaris en la formació contínua del professorat de l'ensenyament secundari, entre els quals trobem:

1) Organitzar i animar situacions d'aprenentatge

2) Gestionar la progressió dels aprenentatges

3) Elaborar i fer evolucionar dispositius de diferenciació

4) Implicar l'alumnat en el seu aprenentatge i en el seu treball

5) Treballar en equip

6) Participar en la gestió de l'escola.

7) Informar i implicar els pares i mares

8) Utilitzar les noves tecnologies

9) Afrontar els deures i els dilemes ètics de la professió

10) Organitzar la formació contínua

Tanmateix destaca la importància de la competència "Construir i planificar dispositius i seqüències didàctiques", que és una altra competència necessària que cal posseir i sobre la qual assenyala:

"Una situació d'aprenentatge s'inclou en un dispositiu que la fa possible $i$ de vegades en una seqüència didàctica en la qual cada situació és una etapa en una progressió..."

Els conceptes de dispositiu i de seqüència didàctica posen l'accent en el fet que una situació d'aprenentatge no es produeix a l'atzar, sinó que la genera un dispositiu que situa els alumnes davant d'una tasca que s'ha de complir, un projecte per realitzar, un problema per resoldre. No existeix un dispositiu general: tot depèn de la disciplina, dels continguts específics, del nivell dels alumnes, de les opcions del professor.

Per altra banda, la preocupació per la formació dels futurs professors i professores dels nivells d'ensenyament secundari, ha de comprendre com- 
petències en diversos camps que podem explicitar en els següents termes, segons Joan Badia, del Departament d'Educació de la Generalitat de Catalunya:

a) Millor coneixement de base lingüística $i$ dels processos psicolingüístics $i$ sociolingüístics. Millorar el domini personal de les llengües oficials, del seu ús oral i escrit i de la seva didàctica és una necessitat imperiosa, ja que els docents exerceixen la seva professió a través precisament de l'ús del llenguatge i a més les habilitats lingüístiques són la base de l'aprenentatge.

b) Domini de les noves tecnologies aplicades a la didàctica. El mestre i la mestra del segle XXI han de posseir un domini extens i intens de les TIC, tant referent a l'ús de programari general (processadors de textos, bases de dades...), com específic de les diferents àrees d'aprenentatge. Igualment han de saber buscar recursos en la xarxa i implementar la docència valent-se de les noves tecnologies. Al mateix temps han de tenir suficients coneixements sobre comunicació audiovisual a fi de poder donar una educació de qualitat i quant a la lectura de la imatge al seu alumnat.

c) Domini d'un idioma a nivell de suficiència. Els professors de secundaria, a més de conèixer l'idioma matern, haurien de ser capaços de fer classes en un altre idioma (que seria anglès, francès), a més de saber ensenyar-lo com a llengua. Per a això la Universitat haurà d'oferir més oportunitats per al seu perfeccionament: més hores d'ensenyament, cursos paral·lels, accés fàcil a escoles d'idiomes universitàries, beques Erasmus, etc.

d) Recursos per a intervenir en una aula intercultural. Les aules de moltes escoles estan cada vegada més plenes d'un alumnat procedent de diferents països del món, amb una varietat de llengües i, sobretot, de cultures. Els mestres i les mestres del nostre segle han de saber tractar de manera adequada aquestes situacions, amb recursos funcionals (coneixements) suficients per a una correcta integració de tot l'alumnat al context social, lingüístic i cultual del país d'acollida.

Finalment (vegeu quadre 1, pàgina següent), detallem algunes de les característiques que, segons la nostra manera de veure, haurien de tenirse en compte en la formació del professorat de secundària.

A tall de síntesi volem evidenciar que les competències que hem al-ludit posen de manifest les següents conclusions o eixos essencials que hauri- en de estar presents en el perfil professional del professorat de secundària:

- L'aparició de més diversitat en les aules, que demana al professorat la qualificació suficient per donar a cada alumne un tractament adequat, d'acord amb les seves necessitats específiques.

- El creixement vertiginós de les tecnologies de la informació i comunicació té repercussions en l'educació actual.

- La nova realitat dels centres educatius, davant de la generalització de les etapes obligatòries, exigeix posar especial atenció en tots aquells factors que condicionen un clima favorable per a la convivència. El nou docent ha de conformar el seu perfil professional amb el foment de les habilitats i relacions interpersonals i interinstitucionals, de manera coherent i adequada.

- L'anàlisi i la reflexió sobre la formació inicial i permanent de caràcter epistemològic de la disciplina a impartir i de la preparació psicopedagògica, així com la preparació pràctica inicial per abordar en solitari l'exercici de la docència.

\section{BIBLIOGRÀFIA}

ANECA (2005). Libro Blanco. Titulo de Grado en Magisterio. Vol.1.

Bunk, G. P. (1994). La transmisión de las competencias en la formación y perfeccionamiento profesionales en la RFA. Revista CEDEFOP, n.1, p. 16.

Delors, Jacques. (1996). Educació: Hi ha un tresor amagat a dins. Informe per a UNESCO de la Comissió Internacional sobre Educació per al segle XXI. Barcelona, Centre UNESCO de Catalunya.

Echeverría, B. (2001). Gestión de la Competencia de Acción Profesional. Revista de Investigación Educativa, 20 (1), pp.7-43.

Fallows, S.; Steven, C. (ed.), (2000): Integrating key skills in higuer education. London: Kogan Page.

Gómez E., Jairo (2004). “Lineamientos pedagógicos para una educación por competencias". En El concepto de competencia II. Una mirada interdisciplinar. Santa fe de Bogotá. Sociedad Colombiana de Pedagogía.

Le Boterf, G. (1998). La ingeniería de las competencias, D'organisation, n.6, p. 23.

Pacheco, Augusto (2005). Las competencias en la enseñanza escolar. Document policopiat.

Perrenoud, Philippe (2004). Diez nuevas competencias para enseñar. Barcelona: Graó. 
Proyecto Tunnig (2003). Tunning Educational Structure in Europe. Informe final. Bilbao: Universidad de Deusto.

Trujillo S., F. Objetivos en la enseñanza de lenguas extranjeras: De la competencia lingüística a la competencia intercultural. Comunicación presentada en el Congreso nacional "Inmigración, Convivencia e Interculturalidad", organizado en
Ceuta por el Instituto de Estudios Ceutíes (Novembre, 2001).

Zarifian, PH. (2001). Le modèle de la compétence. Paris: Éditions Liaisons.

Zabalza, M. A. (2004). Los cinco miuras de la convergencia europea. Crónica Universia:

http://www.universia.es/portada/actualidad/notici a_actualidad.jsp?noticia=76168. (Data de consulta: 30 d'octubre de 2004).

\begin{tabular}{|c|l|}
\hline $\begin{array}{c}\text { Àmbits de } \\
\text { competències }\end{array}$ & \multicolumn{1}{c|}{ Característiques } \\
\hline & - Tenir una preparació adequada i suficient en continguts científics i psicopedagògics. \\
- Ser conscient i saber justificar els criteris que regeixen la selecció dels coneixements i \\
continguts a ensenyar.
\end{tabular}

Quadre 1. Arsenal de competències del professorat de secundaria. (Elaboració pròpia a partir de la bibliografia consultada). 